\title{
Decision making in head injury management in the Edwin Smith Papyrus
}

\author{
Gonzalo Moreno Sanchez, M.D., ${ }^{1}$ AND Alwyn Louise Burridge, M.A. ${ }^{2}$ \\ ${ }^{1}$ University of Arizona Egyptian Expedition, Tucson, Arizona; and ${ }^{2}$ University of Toronto, \\ Ontario, Canada
}

\begin{abstract}
$\checkmark$ The Edwin Smith Papyrus (circa 1650-1550 BC) is a didactic trauma treatise of major interest to neurosurgery, as it deals primarily with cranial and spine injuries. Information regarding the patient's condition is conveyed in the papyrus with sufficient clarity to allow a clinical assessment of each injury. The ancient Egyptian physician/teacher lists the key diagnostic elements in each case, and then pronounces his opinion of the treatment potential in one of three verdicts: 1) "a medical condition I can treat;" 2) "a medical condition I can contend with;" or 3) "a medical condition you will not be able to treat." The structural organization of the text according to regional injuries of increasing severity permits analysis of sequential cases, and makes it possible to determine which clinical features led the ancient Egyptian physician to give the first or second verdict in the less severe injuries, but the third in the worst cases. Interestingly, the ancient physicians were not deterred from contending with injuries in the presence of basilar skull fractures, traumatic meningismus, skull perforation without overt neurological deficit, drowsiness, limited facial fractures, or closed head injuries without depressed fragments. Factors identified as determinant for the third verdict in head injuries are depressed skull fragments, dura laceration with exposed brain, infected cranial wounds/tetanus, major craniofacial fractures, deep skullpenetrating stab wounds, and aphasia. This study describes three case sequences of head injuries.
\end{abstract} (DOI: 10.3171/FOC-07/07/E5)

\section{Key Words • Ancient Egyptian medicine • Edwin Smith Papyrus • history of neuroscience}

$\mathrm{T}$ HE EDWIN SMITH PAPYRUS is a 3500-year-old rolled document that it is remarkably whole, with only the beginning section being fragmentary. It is written in Hieratic, the cursive version of ancient Egyptian hieroglyphics, with a reed pen on papyrus. The renowned Egyptologist James Henry Breasted labored for nearly a decade to decipher this difficult text and finally published his results in 1930 under the title The Edwin Smith Surgical Papyrus. ${ }^{8}$ With his work, he gave to the world of medicine and history the most outstanding medical document from antiquity. Understanding the medical and neurological importance of this document, Breasted elaborated extensively on its anatomical and topographical organization, the types of wounds described, and the individual case structure of each section.

The ancient scribe used two colors of ink within the text: red, from ground ochre, used to highlight divisions between cases and details of significant importance, and black for the body of the text. In Breasted's translation, with attention to the particular colors used, he assigned case numbers with the following subdivisions: "Title," "Examination," "Diagnosis," "Treatment," and "Glosses," (the definitions found at the end of most cases). We main-

Abbreviation used in this paper: LSI = local and systemic infection. tain a similar organization in the present study, but in keeping with the original Hieratic text that does not bear the terms used by Breasted, we used the following section translations that more appropriately capture the meaning of the original text: "Introductory Heading," "Significant Symptoms," "Diagnosis," and "Recommended Treatment." The red and black ink regimen of the original text is faithfully reproduced, and the translations provided are written in italics. Although the translations lack the smoothness of modern speech, the exact phrasing of the ancient Egyptian language has been maintained to preserve the accuracy of the translation. The only deviation from the original papyrus in this study is the addition of bullet points to highlight individual points within the long Egyptian sentences. Careful scrutiny of the Hieratic text suggests that this document was written no later than the 17 th Dynasty circa $1650-1550 \mathrm{BC}$, at the end of the Second Intermediate Period. This period was a time fraught with internecine wars in ancient Egypt, making the treatment of battle wounds an important concern.

\section{History and Translation of the Edwin Smith Papyrus}

The medical importance of this papyrus was recognized soon after it was discovered. In the spring of 1925 , Breasted met Harvey Cushing and shared with him the 
first appearance in ancient medical literature of the word "brain" in the Edwin Smith Papyrus. This document has since been duly noted by neurosurgeons, ${ }^{5-7,11,14-17,23,26,31,33}$ neurologists, ${ }^{12,19}$ medical historians, ${ }^{28}$ and related specialists. $^{21,25}$ Although not the first, it was Wilkins' publication of an excerpt of the Edwin Smith Papyrus in 1965, ${ }^{9}$ in Neurosurgical Classics, that caused this ancient medical document to be well-known to the neurosurgical community. Other neurosurgeons' subsequent involvement with this papyrus includes the work of Alexander Brawanski ${ }^{6}$ who analyzed Head Injury Cases 1 through 8, and later Cases 9 through 14; Paul Chapman ${ }^{11}$ who identified the frontal sinus as the anatomical site of injury in Case 7; and the work of Hughes, ${ }^{20}$ Goodrich,,${ }^{15,16}$ Feldman, ${ }^{14}$ Sanan and Regenchari, ${ }^{30}$ and Brawanski, ${ }^{6}$ who analyzed the spine trauma cases.

Breasted's translation of the Edwin Smith Papyrus has some difficult passages that have hampered modern interpretations by Egyptologists relying on the 1930 rendering of the papyrus. Great strides have been made in the field of translating ancient Egyptian hieroglyphics in the intervening 80 years since Breasted's translations, with refinements in both grammar and vocabulary. Various revisions and translations have followed Breasted's work, most notably Wolfhart Westendorf's serial studies on the Smith Papyrus published between 1966 and 1999, ${ }^{34}$ the works of Thierry Bardinet in $1995,{ }^{3}$ and that of James Allen in $2006 .{ }^{1}$ All of these authors have contributed important details and clarifications on specific points of the original translation. The primary consideration, however, of giving this original medical document the closest medical interpretation has only recently been (partially) addressed. Both authors of the present study are engaged in a complete translation of the Edwin Smith Papyrus in book form, to be titled: The Edwin Smith Papyrus-A Medically Based Translation From the Original Ancient Egyptian Hieratic Document, in which Breasted's masterful translation is preserved and strict adherence to words and word sequences has been observed, while giving medical primacy to word choices. By revisiting the original Hieratic text, it is now possible to correct and clarify many previously enigmatic terms and phrases. The resulting document is remarkably logical from a contemporary medical viewpoint.

Cases in the papyrus are individually presented as "Type Cases." Each is presented in identifiable segments corresponding with the case heading, instructions for examining the patient, and notes on what is to be found on examination. These sections form the elements for making a diagnosis and for the prognostication of success in treatment. Directions follow each case, and often the author of the papyrus gives a set of appropriate definitions of unfamiliar terms as a guide. The entire text stands out as a teaching manual. . $^{8,10,29}$

The ancient Egyptian physician expresses case treatability with one of three verdicts: 1) "This is a medical condition I can treat;" 2) "This is a medical condition with which I shall contend;" and 3) "This is a medical condition you will not be able to treat." The second verdict implies uncertainty about the success of treatment, but asserts a willingness to try to treat the patient anyway. The third verdict in most cases indicated that the ancient physician was not hopeful concerning the success of treatment (althought it was nonetheless customary to provide sup- portive treatment, close observation, and comfort measures).

Reflecting their elaborate methodology, the ancient Egyptian physician presents the injuries according to key examination findings, given with sufficient clarity to allow modern readers to form a medical opinion of the type of injury and of the patient's condition. Egyptian clinical experience led the author (or authors) to record features that were important in formulating a verdict, and to note relationships between head or spine injuries and their neurological consequences. . $^{8,22}$ Although our current understanding of a specific trauma sign or injury is much more complete, the factors that were singled out by Egyptian healers as being significant remain important in our modern practices. As Chapman ${ }^{11}$ has pointed out, the injuries described in the Edwin Smith Papyrus would not be uncommon today in emergency department of any large city hospital. Even across millennia, we face the same challenges. ${ }^{5}$ Of the 48 cases presented in the Edwin Smith Papyrus, there are 14 head injuries, seven cervical injuries, and one lumbar injury, all of interest to the neurosurgeon. Because the injuries presented in the papyrus for a specific anatomical area are presented in order of increasing severity, it is possible to understand the factors that guided the ancient Egyptian physicians to reach a verdict in cases that otherwise appear to be of similar gravity. The study of such features is precisely the purpose of the present analysis.

\section{Translation Methodology}

The original document draws attention to titles, diagnoses, and definitions of particular importance (such as the key features necessary in determining the extent of injury) using red ink (Fig. 1). We have translated the text in phrases in keeping with the format of the Egyptian grammatical structure of the original Hieratic document, which uses series of phrases to point out significant symptoms. The original document was written in sections. These are referred to as "Plates," and they bear a variable number of lines of text, ranging from 20 to 26 .

\section{Group I: Severe Head Injuries with Compound Skull Fractures}

\author{
Case 4: Head Injury with Compound, Displaced, \\ Elevated Skull Fractures \\ [translation of Hieratic text of Edwin Smith Papyrus: \\ Plate II, Lines 2 to $11^{8}$ ]
}

Translations.

Introductory Heading. Medical instructions for an oozing wound from a gash/cut in his head, that has penetrated to the bone and his cranium is split. (Referring to a large fragment fracture classified by the ancient physicians as a $p \check{s} n$, probably pronounced "peshen.")

Significant Symptoms. If you examine a man for an oozing wound from a gash/cut in his head, that has penetrated to the bone and his cranium is split (large fragment fracture).

-You have to probe his wound. Should you find some- 


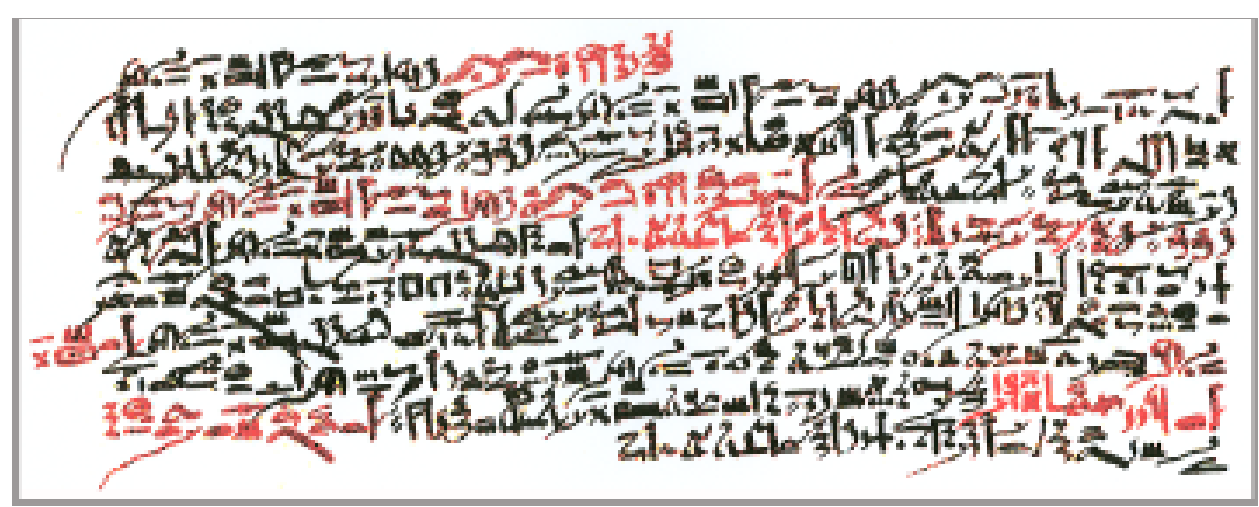

FIG. 1. The Edwin Smith Papyrus, Case 4 of the original Hieratic document (with darkened background removed).

thing there that is "alarming" under your fingers, and if it is very wobbly; ${ }^{5}$

- and has the swelling which is over it protrudes;

- He bleeds from both his nostrils;

- and his ears;

—and if he suffers stiffness in his neck;

- and he is unable to look at his arms and his chest,

Diagnosis Section. . . . then you are to say about him:

"One who has an oozing wound from a gash/cut in his head, that has penetrated to the bone: His cranium is split (large fragment fracture)

- He bleeds from both his nostrils and ears

- He suffers stiffness in his neck:

(This is) a medical condition with which I shall contend."

Recommended Treatment. Because you find that man with a split (large fragment fracture) fracture of his cranium: You must not bandage it.

-Put [him] on the ground, upon his resting place, until the time of his suffering passes. It means, his treatment is sitting upright.

-Make for him: two supports of brick (to maintain his upright position) until you know that he has passed the crisis.

-Then, you should put oil on his head and soften (massage) his neck area and shoulders.

-You should do likewise for any man you find with a displaced fracture of his cranium.

Definitions and Terminology. Note: The ancient Egyptian scribe used these notes (termed "glosses" by Breasted) to clarify specific terms that would not otherwise be familiar to the novice medical practitioner or lay person. Although the original Hieratic text depended only on red ink to separate these notes, for the sake of continuity, this translation follows the accepted alphabetical system established by Breasted in 1930 .

A: As for a split fracture of his cranium ( $p$ šn) (large fragment fracture), it means: a plate of bone separates from [another] plate of bone of the vault of his head, while the fragments remain in the tissue of his head and do not come out.

B: As for: the swelling which is over it protrudes greatly: it means the swelling which is over that (displaced) fracture, rises upward (is elevated above the fracture).

C: As for: you know he has passed the crisis: it means saying that you know whether he will die or he will live because of it. It is a medical condition with which I can contend.

Commentary. In Case 4, the wound characteristics indicate that a $p \check{s} n$ is a compound fracture in which large bone plate disruption has occurred, with pieces displaced and elevated. ${ }^{17,22,26,27}$ This implies a tangential blow to the head by a sharp, heavy, broad-bladed weapon, such as the broad axe (Fig. 2) ${ }^{8,12}$ Definition A provides a clear explanation of this type of injury, and Definition B explains its external appearance. Bleeding is present from the nose and ears, suggesting to us the presence of basilar skull fractures. ${ }^{22}$ The patient's neck rigidity is evident when he attempts to follow commands to look at his shoulders or his chest. Considering the severity of the head injury, traumatic subarachnoid hemorrhage would be the likely source of this rigidity. ${ }^{12}$ It appears that the ancient Egyptian physicians had a fair understanding of the origin of neck rigidity as given earlier in the papyrus, in Case 3, Definition C, when referring to this finding in a compound perforated skull fracture: "As for he suffers from stiffness in his neck, it means stiffening from his having previously been injured, this having migrated to his neck, so that his neck is suffering from it." Remarkably, the physician concludes that neck rigidity is a consequence of the head trauma.

This is undoubtedly a significant injury, but Verdict 2 is issued. Treatment consists of quiet rest in a sitting position with brick supports until the patient has passed "the crisis." The exact meaning of "crisis" is given in Definition C: "[...] until you know whether he will die or he will live because of it."

Topic of Case 5: Head Injury with Compound, Comminuted, Depressed Skull Fracture

[translation of Hieratic text of Edwin Smith Papyrus,

Plate II, Lines 11 to $17^{8}$ ]

\section{Translations}

Introductory Heading. Instructions regarding an oozing wound from a gash/cut in his head, that has smashed in (sd, pronounced sedj) his cranium.

Significant Symptoms. - Then you have to probe his wound.

-Should you find that fracture that is in his skull deep and sunken under your fingers, 


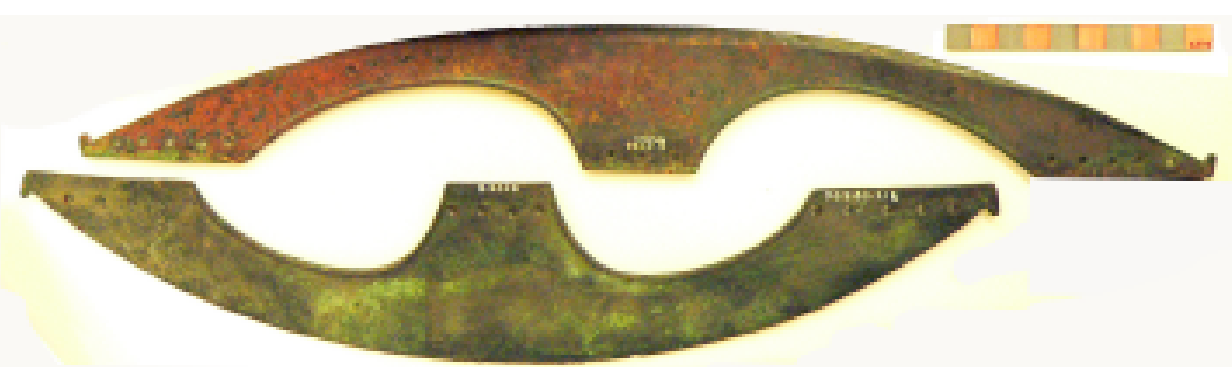

FIG. 2. Middle Kingdom broad axe blades: the weapon responsible for the type of injury described in Case 4. (Used with permission from Royal Ontario Museum.)

- and a swelling which is over it protrudes,

—and he bleeds from his nostrils

—and his ears,

—and he suffers stiffness in his neck,

- and has found he is unable to look at his shoulders

and (down at) his chest.

Diagnosis Section. Then you are to say about him: "One who has an oozing cutting wound in his head, which has penetrated to the bone and smashed in his cranium, (comminuted depressed skull fracture) who suffers from stiffness in his neck: (This is) a medical condition you will not be able to treat."

Recommended Treatment. Do not bandage it.

- Secure him to his resting place, until the time of his crisis passes.

Definitions and Terminology. A. As for a smash fracture in his cranium: it means the bones created by that smash are depressed into the interior of the vault of his skull (comminuted depressed fracture). The book of The Nature of [His] Wounds says, regarding smash fractures: "the vault of his skull is in many fragments, that are depressed into the interior of his cranium."

Commentary. Case 5 is a "comminuted, depressed skull fracture, in which bone fragments are felt under the examiner's fingers. There is also evidence to suggest the presence of basilar skull fractures ${ }^{22}$ and meningismus, but, in this case, the patient is assigned Verdict 3: "(This is) a medical condition you will not be able to treat." The patient is managed by rest and physical support and does not receive bandaging. The mechanism of injury in Case $5 \mathrm{im}-$ plies a direct, shattering blow that drove bony fragments into the cranium. This type of injury could have been produced by a weapon such as a mace (Fig. 3). Such an injury is obvious over the right zygomatic-maxillary area in the mummy of the 17th Dynasty King Seqenenre Tao, who died in battle, circa 1574 BC. ${ }^{4,25}$

Topic of Case 6: Head Injury with Compound,

Comminuted, Depressed, Skull Fracture, and Dura

Laceration

[Translation of Hieratic text of Edwin Smith Papyrus,

Plate II, Line 17 through Plate III, Line $1^{8}$ ]

\section{Translations}

Introductory Heading. Medical instructions for an oozing gash/cutting wound in his head that penetrates to the bone, smashing in his cranium and exposing the brain in his cranium.
Significant Symptoms. If you examine a man for an oozing gash/cutting wound in his head, that penetrates to the bone, smashing in his cranium and exposing the brain in his cranium:

-You have to probe his wound.

-Should you find (in) that smash fracture that is in his cranium, ripples (like) those that occur (in) copper in the smelting process,

-and something within that throbs and flutters under your fingers like the weak spot of the crown of a child (fontanelle) not yet fused and made 'whole'. Once that has taken place, there is no throbbing and fluttering under your fingers, unless broken open to the brain in his cranium.

- He bleeds from his nostrils,

- He suffers with stiffness in his neck.

Diagnosis Section. (This is) a medical condition you will not be able to treat.

Recommended Treatment. You should daub that wound of his with oil.

-Do not bandage it

-Do not put dressings on it until you know he has passed the crisis!

Definitions and Terminology. A. As for "the smashing in of his cranium, and exposure of the brain in his cranium:" the smash (comminuted) fracture is large, opening to the inside of his cranium and the membrane enveloping his brain is ruptured and its fluid falls from the interior of his

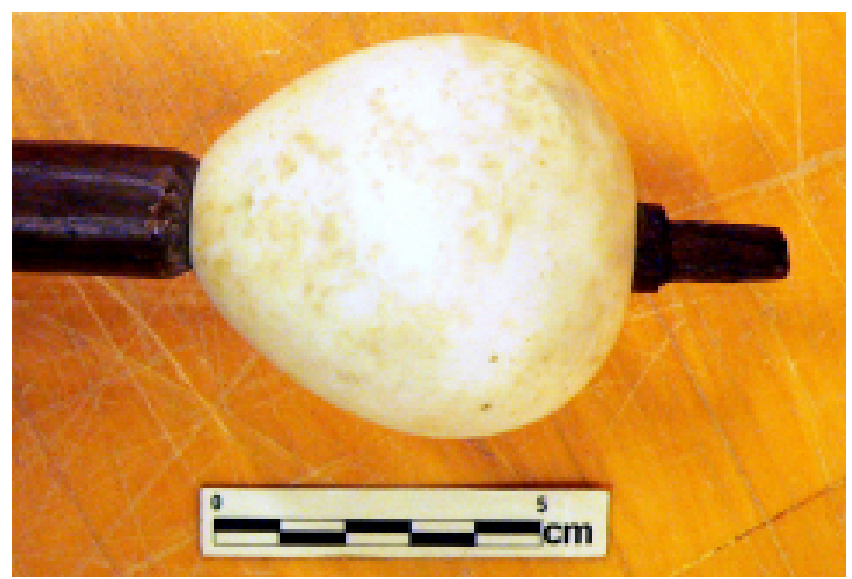

FIG. 3. Picture of an Egyptian Middle Kingdom mace. One weapon responsible for the type of head injuries seen in Cases 5 and 6. (Used with permission from Royal Ontario Museum.) 

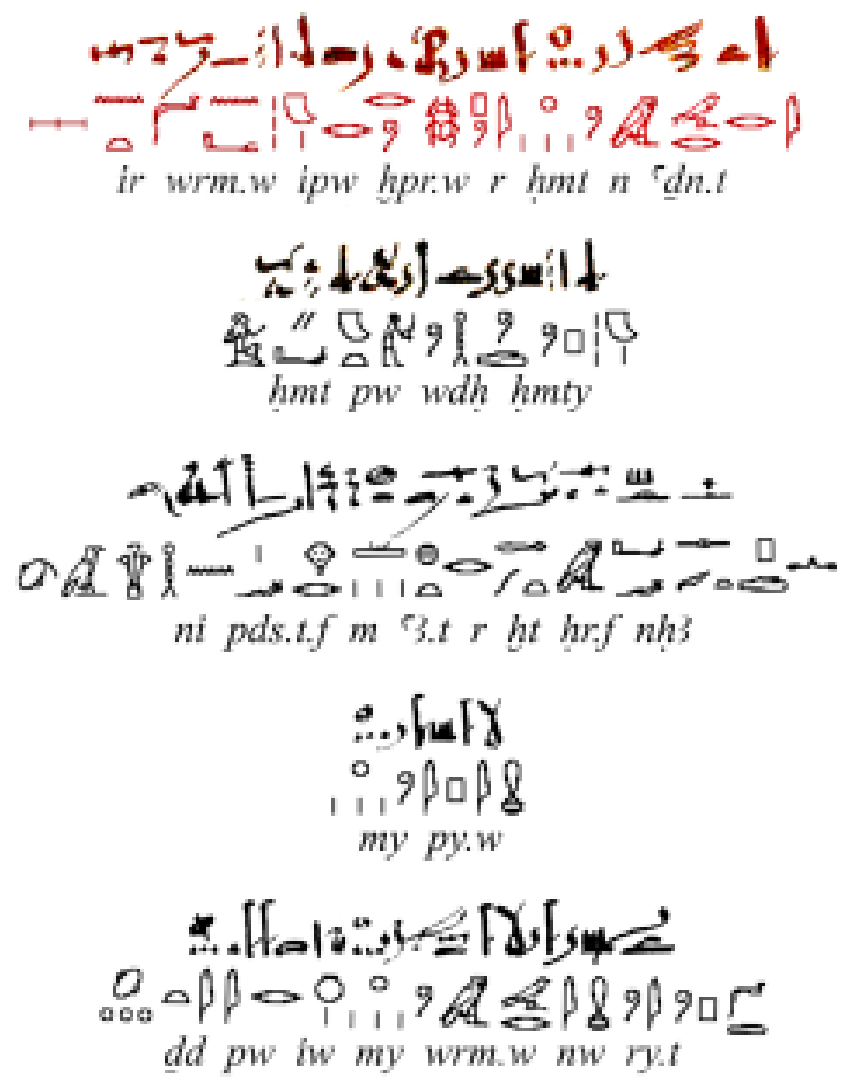

FIG. 4. Case 6. Definition B refers to the external appearance of the surface of the brain being compared to the supernatant that occurs in the process of smelting copper. This figure illustrates the translation steps. Hieratic is written on the top lines with the corresponding hieroglyphics immediately below it; both read left to right. The transliteration, an intermediate step in the translation process, reads left to right under each phrase of ancient Egyptian.

head. B. As for "those ripples that occur on copper through smelting:" It is the copper that a coppersmith pours off before it is forced into a stone mould because of something on it that is foreign (impurities) like wrinkles on it. That is to say, "like ripples of elimination/exclusion." 18

Commentary on Case 6. Case 6 represents an injury of the highest severity in which there is laceration of the dura, exposing the brain (Fig. 4.) Findings on visual inspection and palpation of the pulsating brain surface are extraordinary, as are the physician's explanations of a pulsating fontanelle, and of the dura mater and spinal fluid (Fig. 5). The text also explains that the pulsations of the dura disappear when the fontanelle is closed unless an injury of this nature occurs. The patient described also shows signs of meningismus and basilar skull fractures. The physician's opinion in this case is, understandably, Verdict 3. Still, treatment measures are recommended, two of which are of particular interest for their strong negative commands: "Do not bandage, do not apply dressings, until you know he has passed the crisis."

\section{Decision Making in Cases 4, 5, and 6}

All three of these cases are severe head injuries accompanied by clinical evidence of basilar skull fractures and meningismus. The treatment measures are common to all three cases and are implemented in all, despite the differing verdicts. We speculate that the verdict in Case 4 is related to a less severe head injury, possibly produced by a tangential blow to the cranium with a sharp weapon. Although this blow caused the skull to split into large fragments, the original force would quickly dissipate, resulting in less damage to the brain, and it could provide some degree of intracranial decompression. The mechanism of injury in Case 5 implies a higher degree of direct brain injury with indriven bone fragments. The same mechanism and effects are worse yet in Case 6 because of exposed brain and cerebrospinal fluid leakage. A rendering of Verdict 3 is understandable in these later cases.

\section{Group II: Head Injury with Frontal Stab Wound Penetrating Air Sinus}

Topic of Case 7A: Frontal Stab Wound with Compound Skull Fracture Penetrating the Frontal Air Sinus [Translation of Hieratic text of Edwin Smith Papyrus, Plate III, Lines 2 to $8^{8}$ ]

\section{Translations.}

Introductory Heading. Medical instructions for an oozing gash/cutting wound in his head penetrating to the bone, and perforating the membranous lining of his cranium.

Significant Symptoms.

-Then you have to probe his oozing wound, that is greatly disturbed because of it.

- Then you are to make him raise his head,

- and it is painful for him to open his mouth

- and his heart/mind is feeble in speaking.

-If you observe his spittle hanging from his lips, not having fallen to the ground,

- while he bleeds from his nostrils and his ears,

- and he suffers stiffness in his neck,

- and he has found he is unable to look to his shoulder joints and his sternum.

Diagnosis Section. Then you are to say about him: "One suffering from an oozing gash/cutting wound in his head

- penetrating to the bone,

- and perforating the membranous lining of his cranium.

- the ligaments (cords) of his jaw are contracted,

- while he bleeds from his nostrils

- and his ears,

- and he suffers stiffness in his neck,

(This is) a medical condition with which I can contend."

Recommended Treatment. As soon as you find that man, the ligaments his jaw contracted,

-you then have to place on him, something that has been made hot, until he is comfortable: "a roll of cloth for his mouth,"

-then you have to bandage him with oil, and honey dressing until you know that he has passed the crisis.

Commentary. Case 7A represents a moderately severe head injury to the frontal area with perforation of the cavity of the air sinus. ${ }^{11}$ There are also signs of basilar skull fracture, meningismus, and jaw stiffness. The patient ap- 
pears to be lethargic but he is able to follow commands. Verdict 2 is rendered, and the recommended treatment is primarily aimed at the symptomatic jaw muscle contraction. This symptom could be heralding the full-blown complication that follows.

Case 7B: Frontal Stab Wound with Compound Skull

Fracture Penetrating the Frontal Air Sinus

[The patient has developed ti3 infection (tetan-

us. $)^{2,8,11,12,24,25}$ Translation of Hieratic text of Edwin Smith Papyrus, Plate III, Lines 8 to 13-formerly known as "Second Examination and Diagnosis" in Breasted's 1930 translation. ${ }^{8}$ ]

Translations.

Introductory Heading. An oozing cutting wound in his head which penetrates to the bone, the membranous-lined cavities of his cranium having been perforated. The patient has developed tetanus (ti3).

Significant Symptoms. Note: The presence of local and systemic infection is marked by the abbreviation LSI. The signs of tetanus, a condition the ancient Egyptians called "Ti-a" 2 are indicated by "ti3" in the translation.

If however, you find that man, his flesh having developed fever because of that oozing wound which is in the membranous lining of his cranium and consequently has developed tetanus (ti3) because of that wound,

- then you should place your hand on him and should you find his forehead as one being clammy with perspiration (LSI)

- the ligaments of his neck are as those which are taut, (opisthotonus) (ti3)

-his face is ruddy, (LSI)

- his teeth are shining ${ }^{2}$ (risus sardonicus) (ti3)

-the odor from his calvaria (literally, the "casket" of his head) is like the urine of goats (LSI)

-his mouth is immobile, (trismus) (ti3)

-his eyebrows quiver (ti3)

-his face is like something weeping (ti3).

Diagnosis Section. Then you are to say about him: "One suffering from an oozing gash/cutting wound in his head penetrating to the bone, perforating the membranous lining of his cranium,

-he has developed (tiA) tetanus,

- his mouth is immobile

-he suffers stiffness in his neck

(This is) a medical condition [you] will not be able to treat."

Case 7C: Frontal Stab Wound with Compound Skull

Fracture Penetrating the Frontal Air Sinus:

Course Stabilizing

[Translation of Hieratic text of Edwin Smith Papyrus,

Plate III, Line 15 to Plate IV, Line 4; note that Breasted's "Third Examination" and "Treatment" (Plate III, Lines 13 to 15$)$ were omitted here as they are not applicable in this verdict analysis.]

Definitions and Terminology.

A: As for: "the perforation of the membranous-lining of what belongs to a plate of bone." Its meaning concerns the plate of bone, which is his cranium: there exists a leathery membrane.

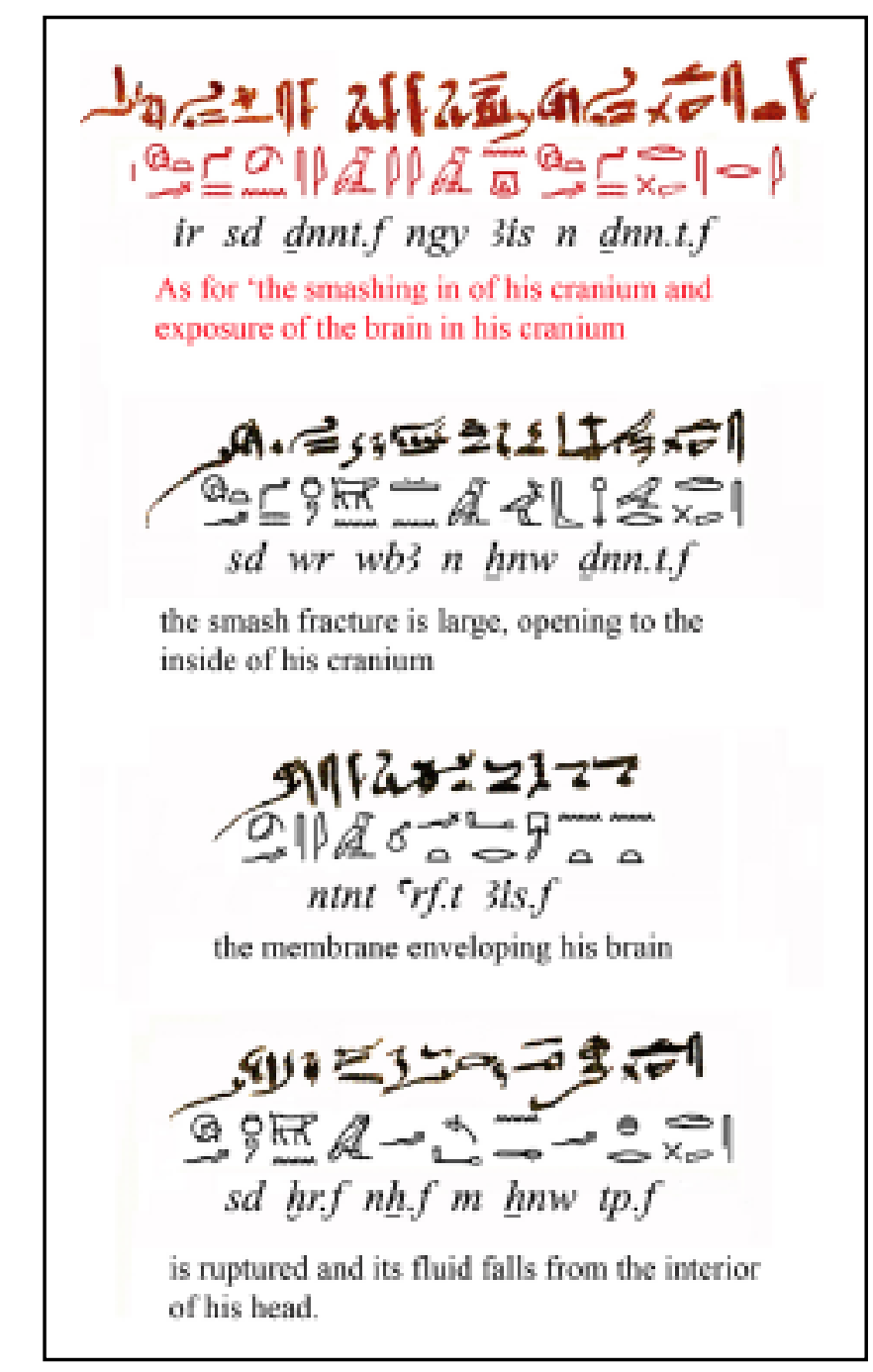

FIG. 5. Case 6. Definition A refers to the brain, dura, and cerebrospinal fluid.

B: As for: 'the cords of his jaw being contracted', it means stiffening by the ligaments of the ends of his rami, which are fastened to his temporal bone. The ends of his mandible: it means no moving 'back and forth'. It was not comfortable for him to open his mouth because of his pain. (ti3)

$\mathrm{C}$ : As for: "the cords of his jaw," they are the ligaments that bind the two ends of his mandible, like saying the cord is something, consisting of rope. (ti3)

D: As for: "his forehead is clammy with perspiration," it means that his head sweats a little, like something damp. (LSI)

E: As for: "the ligaments of his neck being taut," it means that the ligaments of his neck are taut and stiff from his injury. (ti3)

F: As for: "his face is ruddy and red," it means that the color of his face is like the color of fruit that is red. (LSI)

G: As for: "the odor of the chest/vault of his head like 


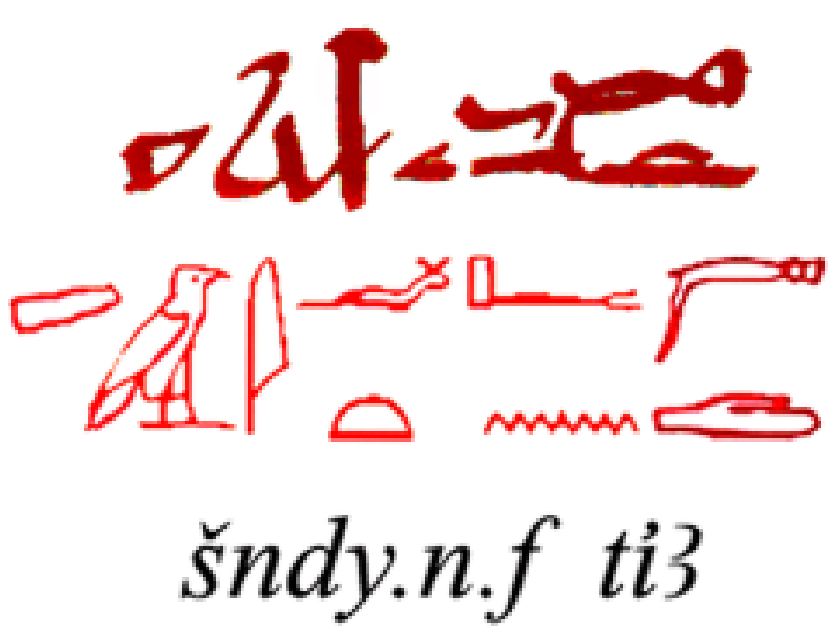

FIG. 6. Case 7. Diagnosis section: the hieroglyphic writing of "he has developed ti3 (tetanus)."

the urine of goats," it means that the odor of the crown of his head is like the urine of goats. (LSI)

$\mathrm{H}$ : As for: "the chest of his head," it is the centre of the crown (of his head) in the vicinity of his brain. This means: that has the form of a chest/box.

I: As for: "his mouth is bound; his eyebrows are askew," his face is something like "he weeps." It means: he is not able to open his mouth and his speech is distorted. His eyebrows droop downwards, not drawing upward, remaining unclosed (literally: "not covering down") like one whose face winks, because of weeping. (ti3)

$\mathrm{J}$ : As for "he has become pale and developed severe weakness." It means: Please!/Look! /Come! Do not abandon him in the presence of (this) exhaustion.

Commentary on Cases 7A and B. Case 7B refers to the same case as in 7A, but the patient has developed local and systemic infection, more specifically, signs of tetanus. ${ }^{2}$ This phrase, "...his teeth are shining..." was used to describe activities which are done with the mouth closed and the teeth showing, as in snarling, or humming, or crying, ${ }^{3}$ illustrative of the risus sardonicus of tetanus. Remarkably, the Egyptian physician clearly attributes this complication as originating from the head wound: “...and consequently has developed (ti3) Tetanus because of that wound."

The medical reference for ti 3 in ancient Egypt had identical connotations to those of the English term "lockjaw" when used as an equivalent for tetanus.

Concepts included in Definition "I" suggest a peripheral facial paralysis commonly seen in cephalic tetanus (Fig. 6).

\section{Decision Making in Case 7}

Case 7A, a primary head injury, is a frontal stab wound penetrating the air sinus. This patient is able to follow commands, although he is drowsy. He has meningismus and is bleeding from the nose and ears. Since this is a perforating wound to the forehead, it is likely that the bleeding can be attributed to a deep penetrating sharp object. We are given, in addition, symptoms of pain when opening his mouth, and of contraction of his jaw. At this stage, the patient is treated for his jaw symptoms with local measures.

As one of two possible alternative courses, the situation in Case 7B turns into an infectious complication, most likely by multiple bacteria, but the physician gives us the unequivocal characteristics of tetanus infection. With that development, the prognosis changes from Verdict 2 to 3 . No treatment of any kind is implemented. This predicted outcome was discussed in an unpublished presentation (G. M. Sanchez, 2001).

\section{Group III: Craniofacial Injuries: Stab Wounds of the Temporozygomatic Area}

Case 19: Zygomatic-Temporal Stab Wound

[Translation of Hieratic text of the Edwin Smith Papyrus, Plate VII, Lines 14 to $22 .{ }^{8}$ ]

\section{Translations.}

Introductory Heading. Medical instructions concerning a puncture in his (gmA) temple/zygomatic area.

Significant Symptoms. If you examine a man [for] a puncture [in] his temple/zygomatic area, with a wound on $i t$,

-you have to observe his oozing wound.

-Say to him: "Look at your shoulders."

- and his doing so is painful,

- and he turns his neck only a little,

- and his eye is bloodshot on his side that has that injury,

Diagnosis Section. Then you are to say about him: "One who has a puncture/perforation in his temple,

- and he is suffering from stiffness in his neck:

"(This is) a medical condition I can treat."

Recommended Treatment.-You have to put him upon his resting place, until the period of his suffering is past.

-You should treat with oil and honey, re-dressing every day until he is well.

Terminology Clarification. As for "his two eyes are blood shot and red in color," it means that the color of his eyes is like the color of coriander. The book: What Pertains to the Embalmer/Bandager has said about it: "Both his eyes are red and diseased like an eye at the end of its fatigue."

Commentary. The stab wound to the temporozygomatic area in Case 19 is accompanied by neck rigidity and some degree of orbital injury. Subconjunctival hemorrhage is common in zygomatic fractures ${ }^{29}$ a feature the scribe compares to an eye disease of long standing in his phrase "an eye at the end of its fatigue." It is a penetrating cranial wound with possible traumatic subarachnoid hemorrhage, but the patient is alert and follows commands. These are low velocity injuries with limited penetration, and only focal tissue damage..$^{13,22,32}$ Meningismus is common, ${ }^{12}$ and other symptoms will depend on the trajectory of the offending weapon, and of vessel injury. ${ }^{13,21}$ Verdict 1 is rendered. Bed rest with supportive care and wound care are implemented, until the time of his injury has passed. The allusion to another authoritative text entitled What Pertains to the Embalmer/Bandager indicates the existence of other instructional manuals. 
Case 20. Zygomatic-Temporal Stab Wound with Skull Perforation and Basilar Skull Fracture

[Translation of the Hieratic text of the Edwin Smith

Papyrus, Plate VII, Line 22 to Plate VIII, Line $5^{8}$ ]

\section{Translations.}

Introductory Heading. Medical instructions for an oozing wound in his temple, which has penetrated to the bone and perforated his temple.

Significant Symptoms. If you examine a man for an oozing wound in his temple which has penetrated to the bone, and perforated his temple,

- while both his eyes are bloodshot drops.

- and he bleeds profusely from his two nostrils by little

-If you put your fingers on the mouth of that oozing wound, the disturbance for him is great.

-If you ask about his malady, he cannot speak to you.

- Great tears are falling from his eyes.

- He has to take his hand to his face repeatedly and he rubs both his eyes with the back of his hand like a child does, without his realizing what he is doing.

Diagnosis Section. Then you are to say about him: "One who has a oozing wound in his temple, which has penetrated to the bone and perforated his temple:

— who bleeds from both his nostrils,

- and he suffers stiffness in his neck

- and is aphasic/nonresponsive

(This is) a medical condition you will not be able to treat."

Recommended Treatment. Now when you find that man aphasic/nonresponsive, it means his treatment

should be resting in an upright sitting posture.

-Massage his head with oil.

- Pour milk into the mouth/orifice of both his ears.

Commentary. Case 20 is of a deeper temporozygomatic stab, classified anciently as "thm" (pronounced "Tehem") wound, which has evidently perforated through the skull, nasal cavity and perhaps the orbit(s). The description of the patient's behavior suggests his inability to understand or verbally express himself, and his agitation and frustration are all indicative of aphasia, symptomatic of a dominant hemisphere injury. The patient also has meningismus, is bleeding profusely from his nose, and is possibly blind. Considering the probable trajectory of the weapon, it is possible that there is optic pathway damage. (Similar penetrating injuries are described in van Dellen's Cases 6 and
$8,{ }^{32}$ and in Khalil's Case $3 .^{21}$ ) Verdict 3 does not suggest a positive outcome, but they do treat with the use of the sitting position and soothing measures. Curiously, the patient is given milk into his ears, the reasons for this we can only speculate about.

\section{Decision Making in Cases 19 and 20}

In du Trevon ${ }^{13}$ and van Dellen's ${ }^{32}$ cases, 44 of 250 patients had temporal penetrating stab wounds. Only $30 \%$ of these patients were fully conscious, and $25 \%$ were in coma. Their overall mortality was $26 \%$. The patients represented in Cases 19 and 20 had penetrating injuries to the zygomatic-temporal area. In Case 19, the injury has produced meningismus and there is evidence of unilateral eye involvement as the outstanding symptoms. The physician considers it: "a medical condition which I can treat." (Verdict 1)

Case 20 is in the other extreme of the injuries described in these series. The patient also has meningismus, but the presence of an active nosebleed in a temporal area-penetrating wound suggests that the weapon reached the nasal/ ethmoid complex. An example of an arrow injury through the mouth and into the skull base is shown in the Battle Reliefs of King Sety I on the Temple of Karnak. ${ }^{31}$ Clearly a major neurological symptom about which nothing could have been done in that era, aphasia is treatable with limited success even today.

\section{Conclusions}

A clinical review of severe head injury cases in the Edwin Smith Papyrus indicates that the clinical signs considered important by the physicians in ancient Egypt in their diagnostic and treatability determinations remain important in our present-day assessments of cranial and spinal trauma. A summary of the findings in all cases is given in Table 1. Although limited effective treatments were available, the ancient Egyptian physicians succeeded in establishing a clinical methodology heralding the beginnings of modern medicine.

Our analysis is made possible only by the structured nature of the Edwin Smith Papyrus, with its inclusion of rich anatomical and clinical information reflecting a high level of sophisticated knowledge. ${ }^{10}$ On the basis of this remarkable text, we can reasonably assume that the ancient Egyptians practiced effective diagnoses and trauma

TABLE 1

Summary of cases and clinical decision-making in the Edwin Smith papyrus

\begin{tabular}{clc}
\hline \hline Case No. & \multicolumn{1}{c}{ Modern Clinical Description } & Verdict \\
\hline Group I: & severe head injuries with compound skull fractures & 2 \\
4 & head injury, compound elevated skull fracture & 3 \\
5 & head injury, compound, comminuted, depressed skull fracture & 3 \\
6 & head injury, compound, comminuted, depressed skull fracture and dura laceration & 2 \\
Group II: & head injury with frontal stab wound penetrating the air sinus & 3 \\
7A & frontal stab wound, compound skull fracture with frontal sinus penetration & 1 \\
7B & frontal stab wound, compound skull fracture with frontal sinus penetration, infected, tetanus \\
Group III: & craniofacial injuries with stab wounds of the temporozygomatic area & 3 \\
19 & iemporozygomatic stab wound & \\
20 & temporozygomatic stab wound with skull perforation and basilar skull fracture & \\
\hline
\end{tabular}


management and could render treatment with predictable outcomes based on prior experience.

\section{References}

1. Allen JP: The Art of Medicine in Ancient Egypt. New York: The Metropolitan Museum of Art and Yale University Press, 2005, pp 70-105

2. Bardinet T: Dents et mâchoires das les représentations religieuses et la pratique médicale de L'Egypte ancienne, in Studia Pohl: Series Maior 15. Rome: Editrice Pontificio Istituto Biblico, 1990, pp 169-171

3. Bardinet T: Les Papyrus Médicaux de L'Egypte Pharaonique. Paris: Fayard 1995, pp 493-510

4. Bietak M, Strouhal E: Die Todesumstände des Pharaos Seqenenre (17. Dynastie). Ann Naturhistor Mus Wien 78:45-50, 1974

5. Brawanski A: Die Fäll 1-8 des Papyrus Edwin Smith. Studien zur Altägypstischen Kultur (SAK) 29: S7-S39, 2001

6. Brawanski A: Die Wirbelsäulenverletzungen des Papyrus Edwin Smith (Fall 29-33). Studien zur Altägypstischen Kultur (SAK) 32:59-80, 2004.

7. Brawanski A: Mittelgesichtsverletzungen im Pap. Smith (Fälle 9-14). Studien zur Altägypstischen Kultur (SAK) 35:43-60, 2006

8. Breasted JH: The Edwin Smith Surgical Papyrus. Facsimile and Hieroglyphic Transliteration with Translation and Commentary, in Two Volumes. Chicago: University of Chicago Press, 1930

9. Breasted JH: The Edwin Smith surgical papyrus, in Wilkins RH (ed): Neurosurgical Classics. New York: Johnson Reprint Corporation, 1965, pp 1-5

10. Burridge AL: A study of the Edwin Smith surgical papyrus. JSSEA 24:9-26, 1997

11. Chapman PH: Case seven of the Smith surgical papyrus: the meaning of tpAw. JARCE 29:35-42, 1992

12. Corville CB: Injuries to the skull and brain in ancient Egypt. Some notes on the mechanism, nature, and effects of cranial injuries from predynastic times to the end of the Ptolemaic period. Bull Los Angeles Neurol Soc 14:53-82, 1949

13. du Trevon MD, van Dellen JR: Penetrating stab wounds to the brain: the timing of angiography in patients presenting with the weapon already removed. Neurosurgery 13:905-912, 1992

14. Feldman RP, Goodrich JT: The Edwin Smith surgical papyrus. Childs Nerv Syst 15:281-284, 1999

15. Goodrich JT: History of spine surgery in the ancient and medieval worlds. Neurosurg Focus 16(1):E2, 2004

16. Goodrich JT: Neurosurgery in the ancient and medieval worlds, in Greenblatt SH, Dagi TF, Epstein MH (eds): A History of Neurosurgery: In its Scientific and Cultural Contexts. Park Ridge, Ill: AANS 1997, pp 38-39
17. Gurdjian ES: Impact Head Injury. Springfield Il: Charles C. Thomas, 1975, pp 135

18. Hannig R, Vomberg P: Wortschatz der Pharaonen in Sachgruppen. Mainz: Verlag Phillip von Zabern, 1999, pp 689

19. Helgason CM: Commentary on the significance for modern neurology of the 17th century B.C. Surgical Papyrus. Can J Neurol Sci 14:560-563, 1987

20. Hughes JT: The Edwin Smith Surgical Papyrus: an analysis of the first case reports of spinal cord injuries. Paraplegia 26: 71-82, 1988

21. Khalil N, Elwany MN, Miller, JD: Transcranial stab wounds morbidity and medicolegal awareness. Surg Neurol 35: 294-299, 1998

22. Leetsma JE: Forensic Neuropathology. New York: Raven Press, 1988, pp 191

23. Metzel E: Neurotraumatologie im Alten Ägypten. Neurochirugia 33:78-80, 1990

24. Miller RL: Tetanus after cranial trauma in ancient Egypt. J Neurol Neurosurg Psychiatry 63:758, 1997

25. Nunn JF: Ancient Egyptian Medicine. London: British Museum Press, 1996, pp 171-202

26. Ralston BL: Compound elevated fractures of the skull. J Neurosurg 44:77-79, 1976

27. Ralston BL: Medical reinterpretation of case rour of the Edwin Smith Surgical Papyrus. JEA 63:116-121, 1977

28. Risse GB: Rational Egyptian Surgery: Cranial Surgery Discussed in the Edwin Smith Papyrus. Bull NY Acad Med 48: 145-158, 1972

29. Robinson J, Donald PJ: Management of associated cranial lesions, in Pitts LH, Wagner FC Jr (eds): Craniospinal Trauma. New York: Thieme, 1990, pp 59-62

30. Sanan A, Regenchary SS: The history of spinal biomechanics. Neurosurgery 39:657-669, 1996

31. Sanchez GM: A neurosurgeon's view of the battle reliefs of King Sety I: aspects of neurological importance. JARCE 27: 143-165, 2000

32. van Dellen JR, Lipschitz R: Stab wounds of the skull. Surg Neurol 10:110-112, 1978

33. Walker AE, Udvarheyli GB, Laws ER Jr (eds): The Genesis of Neuroscience. Parke Ridge Il: AANS, 1998, pp 19-21

34. Westendorf W: Papyrus Smith, in Handbuch der Altägypstichen Medizin 2 Handbuch der Orientalistik. Leiden: Brill, 1999, pp 713-718, 724-727

Manuscript submitted April 11, 2007.

Accepted June 15, 2007.

Address reprint requests to: Gonzalo M. Sanchez, M.D., 100 MAC Lane, Pierre, SD 57501. email: gsanchez37@ pie.midco.net. 